\title{
Capital mobility and global factor shocks
}

\author{
Mauro Costantini ${ }^{\mathrm{a}}$, Luciano Gutierrez ${ }^{\mathrm{b}, *}$ \\ a Brunel University, London, UK \\ ${ }^{\mathrm{b}}$ University of Sassari, Sassari, Italy
}

\section{H I G H L I G H T S}

- We focus on the effects of global factors on the saving-investment relationship.

- We show that if investments and savings are affected by idiosyncratic and global components, they must be cointegrated.

- When global shocks are taken into account through common factors, the estimated saving-retention coefficient is close to zero.

\section{A R T I C L E I N F O}

\section{Article history:}

Received 18 April 2013

Received in revised form

3 June 2013

Accepted 7 June 2013

Available online 18 June 2013

\section{JEL classification:}

C31

C33

F32

F41

Keywords:

Saving

Investment

Capital mobility

Panel cointegration

\begin{abstract}
A B S T R A C T
This paper focuses on the effects of global factors on the saving-investment relationship. We prove that, if investments and savings are affected by idiosyncratic and global components, they must be cointegrated to obtain reliable estimates of the saving-retention coefficient. When global shocks are taken into account through common factors, we find that the estimated saving-retention coefficient is close to zero for a panel of 21 OECD countries.
\end{abstract}

(C) 2013 Elsevier B.V. All rights reserved.

\section{Introduction}

In their original study, Feldstein and Horioka (1980) claim that capital mobility is relatively immobile on the basis of a crosssection regression of investment and saving ratios across 16 OECD countries over the period 1960-74. This result has encouraged an immense literature on the subject, and several explanations have been offered (see Obstfeld, 1986; Taylor, 1994; Coakley et al., 1996, 2004; Westerlund, 2006, among others).

In this paper, we focus on the global factors explanation of the Feldstein-Horioka puzzle using a panel cointegration approach. This paper makes some contributions. We prove that, if investments and savings are affected by idiosyncratic and global components, they must be cointegrated to obtain reliable estimates

\footnotetext{
* Correspondence to: Department of Agricultural Sciences, University of Sassari, Via E. DeNicola 1, 07100 Sassari, Italy. Tel.: +39 079229256

E-mail address: lgutierr@uniss.it (L. Gutierrez).
}

of the saving-retention coefficient. ${ }^{1}$ We then estimate the savingretention coefficient for a sample of 21 OECD countries over the period 1970-2008 using the panel CUP-FM estimator of Bai and Kao (2006) that models cross-sectional dependence through a common factor structure. In order to make a comparison, we also apply the panel dynamic OLS (DOLS) and fully modified OLS (FMOLS) estimators of Kao and Chiang (2000) that assume the hypothesis of cross-sectional independence. The results show that the retention coefficient is very close to zero when cross-sectional dependence among countries is taken into account.

The paper is organized as follows. In Section 2, the motivation and methodology are described. Section 3 offers the empirical application.

\footnotetext{
1 Recent works show that saving and investment are nonstationary processes, and the retention coefficient should be interpreted as a cointegration relationship (see, e.g., Coakley and Kulasi, 1997; Caporale et al., 2005).
} 


\section{Motivation and methodology}

As shown by Andrews (2005), cross-section dependence induced by common factors can yield bias and inconsistent estimates in the context of a single cross-section. Since common factors could reflect global shocks (see, e.g., Byrne et al., 2009; Giannone and Lenza, 2010), the Feldstein-Horioka's (1980) estimates based on cross-section regressions may be unreliable. Unfortunately, for a single cross-section, not much can be done about common shocks, but by using panel cointegration analysis that assumes crosssectional dependence through common factors reliable estimates of the retention coefficient can be obtained (see Bai et al., 2009).

In this section, we show that, if savings and investment rates are affected by country-specific and common factor components, they must be cointegrated to obtain reliable estimates of the saving-retention coefficient. To this end, we follow the approach of Gengenbach et al. (2006) and Urbain and Westerlund (2011) that models cross-sectional dependence through common factors. Specifically, we assume that the relationship between investment $\left(I_{i t}\right)$ and saving $\left(S_{i t}\right)$ can be decomposed as

$$
\left[\begin{array}{c}
I_{i t} \\
S_{i t}
\end{array}\right]=d_{i}+\Lambda_{i} f_{t}+e_{i t}, \quad i=1, \ldots, N ; t=1, \ldots, T,
$$

where $d_{i}$ is a deterministic component, $f_{t}$ is a common component that affects all the countries, and $e_{i t}$ is an idiosyncratic (countryspecific) component. The common and the idiosyncratic components can be further partitioned as $f_{t}=\left(f_{t}^{I^{\prime}}, f_{t}^{S^{\prime}}\right)^{\prime}$ and $e_{i t}=$ $\left(e_{\text {Iit }}{ }^{\prime}, e_{\text {Sit }}{ }^{\prime}\right)^{\prime}$.

Assuming for simplicity that the number of common factors for investment and saving is $k_{I}=k_{S}=1$, then the matrix of factor loadings, $\Lambda_{i}$, can be partitioned as

$\Lambda_{i}=\left[\begin{array}{ll}\lambda_{I I i} & \lambda_{I S i} \\ \lambda_{S l i} & \lambda_{S S i}\end{array}\right]$

where $f_{t}$ represents the realization of global shocks for $I_{i t}$ and $S_{i t}$, the factor loadings in $\Lambda_{i}$ denote the sensitivity of the saving and investment to global shocks in country $i$, and $e_{i t}$ accounts for country-specific shocks.

According to Eq. (1), three different cases that involve nonstationarity and cointegration can be distinguished.

(i) If $f_{t}$ is nonstationary and $e_{i t}$ is stationary, investment and saving are nonstationary by definition, and cointegration among them depends on $\Lambda_{i}$. More specifically, if $\Lambda_{i}$ is block diagonal, i.e., $\lambda_{I I i} \neq 0, \lambda_{S S i} \neq 0$ and $\lambda_{\text {ISi }}=\lambda_{S I i}=0$ for all $i$, investment and saving are cross-member cointegrated but are not cointegrated with each other. However, the savingretention coefficient cannot be estimated under this set-up.

(ii) When the common and idiosyncratic components are nonstationary and stationary, respectively, but $\Lambda_{i}$ is no longer block diagonal, saving and investment are cross-member cointegrated as in (i), but they are also cointegrated with each other.

(iii) If the idiosyncratic and common components are both nonstationary, cointegration between investment and saving exists if and only if there is cointegration in the common and idiosyncratic components.

Therefore, we proceed as follows.

1. A preliminary PANIC analysis is carried out on $I_{i t}$ and $S_{i t}$ to test for nonstationarity (see Bai and $\mathrm{Ng}, 2004$ ).

2. (a) If $I(1)$ common factors and $I(0)$ idiosyncratic components are found in 1 , then there is cross-member cointegration (see case (i)). In this case, cointegration between $I_{i t}$ and $S_{i t}$ occurs only if $f_{t}^{I^{\prime}}$ and $f_{t}^{S^{\prime}}$ are cointegrated (see case (ii)). To test for cointegration among common factors, the trace test of Johansen (1988) can be used. (b) If both the common and idiosyncratic components are I(1) (see case (iii)), then we test for common component cointegration (see 2(a)) and for cointegration in the defactored data (using panel tests such as those of Pedroni, 2004), respectively. If both components are cointegrated, then $I_{i t}$ is cointegrated with $S_{i t}$.

In summary, using the previous testing procedure, one is able to estimate the saving-retention coefficient $\beta$ running the following panel regression:

$I_{i t}=\alpha_{i}+\beta S_{i t}+\varepsilon_{i t}$,

if and only if $I_{i t}$ and $S_{i t}$ are cointegrated as a result of case 2(a) or 2(b). Using Eq. (1) and case (ii), we have

$I_{i t}=\alpha_{I i}+\lambda_{I I} f_{t}^{I}+e_{\text {Iit }}$

$S_{i t}=\alpha_{S i}+\lambda_{I S i} f_{t}^{S}+e_{S i t}$.

From (4), it is clear that any linear combination can be written as

$I_{i t}=\alpha_{i}^{\prime}+\beta S_{i t}+v_{i t}$

$v_{i t}=\lambda_{I i} g_{t}+\varepsilon_{i t}^{\prime}$,

where $\alpha_{i}^{\prime}=\alpha_{I i}-\beta \alpha_{S i}, g_{t}=\left(f_{t}^{I}-\frac{\beta \lambda_{I S i}}{\lambda_{I i}} f_{t}^{S}\right)$ and $\varepsilon_{i t}^{\prime}=e_{I i t}-\beta e_{S i t}$. Since $e_{\text {Iit }}$ and $e_{S i t}$ are $I(0)$ by assumption, then $\varepsilon_{i t}^{\prime} \sim I(0)$. Eq. (5) controls for global shocks through common factors and $I_{i t}$ and $S_{i t}$ are cointegrated if and only if $f_{t}^{I}$ and $f_{t}^{S}$ are cointegrated. In the empirical analysis, we use the CUP-FM estimator to estimate Eq. (5). ${ }^{2}$ In order to make a comparison, we also apply the dynamic OLS (DOLS) and fully modified OLS (FMOLS) estimators of Kao and Chiang (2000).

\section{The empirical results}

Our empirical analysis ${ }^{3}$ proceeds in three steps. First, we test for unit root in investment and saving using the PANIC approach. Second, we test for cointegration between those variables. Lastly, Eq. (5) is estimated using the DOLS, FMOLS, and CUP-FM estimators.

We consider a panel of 21 OECD countries over the period 1970-2008. ${ }^{4}$ Data is taken from OECD National and Annual accounts. Savings and investment rates are calculated here as the ratio of savings and investments to GDP, $i_{i t}=\frac{I_{i t}}{Y_{i t}}$ and $s_{i t}=\frac{S_{i t}}{Y_{i t}}$, where $Y$ is GDP, $I$ is the gross capital formation, and $S$ is the sum of consumption of fixed capital and net saving.

As a preliminary step, we use the CD statistics of Pesaran (2004) to test for cross-sectional dependence in the data. The results show evidence of dependence since the statistics for investment and saving are $42.485(0.000)$ and $21.773(0.000)$, respectively ( $p$-values are given in parentheses).

As regards the unit root results, savings and investment rates are nonstationary when the PANIC approach is used (see Table 1). However, we also consider a more powerful panel unit root test of Moon and Perron (2004), $t_{b}^{*}$, since the tests of Bai and $\mathrm{Ng}$ (2004) suffer from a low power (see Gutierrez, 2006). The results show that both idiosyncratic components of saving and investment are stationary. Therefore we proceed to test for cointegration only in the common factors using Johansen's (1988) trace test. The findings show the existence of one cointegrating vector (see Table 2).

\footnotetext{
2 On the CUP-FM estimator, see also Costantini et al. (2013).

3 All results have been obtained using GAUSS 11.0 procedures.

4 The countries included are Australia, Austria, Belgium, Canada, Denmark, Finland, France, Germany, Greece, Ireland, Italy, Japan, Netherlands, New Zealand, Norway, Portugal, Spain, Sweden, Switzerland, UK, and USA
} 
Table 1

Panel unit root results.

\begin{tabular}{lccc}
\hline Unit root & & \\
\hline Variables & $B N_{A D F_{\hat{F}}^{c}}$ & $B N_{Z_{\hat{e}}^{c}}$ & $t_{b}^{*}$ \\
\hline$\left(\frac{I}{Y}\right)_{i t}$ & -1.225 & 4.286 & $-12.182^{* * * *}$ \\
$\left(\frac{S}{Y}\right)_{i t}$ & $(0.652)$ & $(0.000)$ & $(0.000)$ \\
& -2.335 & 0.881 & $-9.482^{* * *}$ \\
$(0.168)$ & $(0.378)$ & $(0.000)$
\end{tabular}

Notes: $B N_{A D F F_{\hat{F}}^{c}}$ and $B N_{Z_{\hat{e}}^{c}}$ denote Bai and Ng's (2004) panel unit root tests on common

factor and idiosyncratic components, respectively. The number of the common factors according to BIC3 Criteria is equal to $1 . t_{b}^{*}$ denotes the panel unit root test of Moon and Perron (2004). p-values are in parentheses.

* Significance level at the $10 \%$.

** Significance level at the $5 \%$.

**** Significance level at the $1 \%$.

Table 2

Cointegration and estimation results.

\begin{tabular}{|c|c|}
\hline \multicolumn{2}{|c|}{ Factor cointegration } \\
\hline$H_{0}: r=$ & Trace statistics \\
\hline 0 & $\begin{array}{l}28.12^{* * * *} \\
(0.003)\end{array}$ \\
\hline 1 & $\begin{array}{c}5.74 \\
(0.219) \\
\end{array}$ \\
\hline \multicolumn{2}{|c|}{ Estimates of Eq. (5) } \\
\hline Method & Coefficient \\
\hline DOLS & $\begin{array}{l}0.512^{* * * *} \\
(0.000)\end{array}$ \\
\hline FMOLS & $\begin{array}{l}0.510^{* * * *} \\
(0.003)\end{array}$ \\
\hline CUP-FM & $\begin{array}{l}0.084^{* * *} \\
(0.042)\end{array}$ \\
\hline
\end{tabular}

Notes: Factor cointegration analysis is performed using the trace test of Johansen (1988). $r$ is the number of cointegrating vectors. As regards the DOLS estimator, the number of leads and lags is set to 2 . With respect to the CUP-FM estimator, the number of common factors is set to 1 , consistently with the unit root results. $p$-values are in parentheses.

* Significance level at the $10 \%$.

Significance level at the $5 \%$.

**** Significance level at the $1 \%$.

Once cointegration is found, we estimate Eq. (5) using the DOLS, FMOLS, and CUP-FM estimators. The results can be summarized as follows (see Table 2). First, all the estimates are statistically significant. Second, the retention coefficient shows higher values when the DOLS and FMOLS estimators are considered. These findings are in line with those obtained in previous studies (see, e.g., Ho, 2002; Coakley et al., 2004; Adedeji and Thornton, 2008). Third, the estimated retention coefficient is very close to zero when the CUP-FM estimator is considered. This highlights that neglecting cross-sectional dependence may bias the savingretention coefficient upwardly.

\section{References}

Adedeji, O., Thornton, J., 2008. International capital mobility: evidence from panel cointegration tests. Economics Letters 99, 349-352.

Andrews, D.W.K., 2005. Cross-section regression with common shocks. Econometrica $73,1551-1585$.

Bai, J., Kao, C., 2006. On the estimation and inference of a panel cointegration model with cross-sectional dependence. In: Baltagi, B.H. (Ed.), Panel Data Econometrics: Theoretical Contributions and Empirical Applications. Elsevier Science, Amsterdam.

Bai, J., Kao, C., Ng, S., 2009. Panel cointegration with global stochastic trends. Journal of Econometrics 149, 82-99.

Bai, J., Ng, S., 2004. A panic attack on unit roots and cointegration. Econometrica 72, $1127-1177$

Byrne, J.P., Fazio, G., Fiess, N., 2009. The global side of the investment-saving puzzle. Journal of Money, Credit and Banking 41, 1033-1040.

Caporale, G.M., Panopoulou, E., Pittis, N., 2005. The Feldstein-Horioka puzzle revisited: a Monte-Carlo study. Journal of International Money and Finance 24, 1143-1149.

Coakley, J., Fuertes, A.M., Spagnolo, F., 2004. Is the Feldstein-Horioka puzzle history? Manchester School 72, 569-590.

Coakley, J., Kulasi, F., 1997. Cointegration of long span saving and investment. Economics Letters 54, 1-6.

Coakley, J., Kulasi, F., Smith, R., 1996. Current account solvency and the Feldstein-Horioka puzzle. The Economic Journal 106, 620-627.

Costantini, M., Demetriades, P., James, G., Lee, L., 2013. Financial restraints and private investment: evidence from a nonstationary panel. Economic Inquiry 51 , 248-259.

Feldstein, M., Horioka, C., 1980. Domestic saving and international capital flows. The Economic Journal 90, 314-329.

Gengenbach, C., Palm, F.C., Urbain, J.P., 2006. Cointegration testing in panels with common factors. Oxford Bulletin of Economics and Statistics 68, 683-719.

Giannone, D., Lenza, M., 2010. The Feldstein-Horioka fact. In: Reichlin, L., West, K. (Eds.), International Seminar on Macroeconomics 2009. In: NBER, University of Chicago Press, pp. 103-117.

Gutierrez, L., 2006. Panel unit roots tests for cross-sectionally correlated panels: a Monte Carlo comparison. Oxford Bulletin of Economics and Statistics 68, 519-540.

Ho, T., 2002. The Feldstein-Horioka puzzle revisited. Journal of International Money and Finance 21, 555-564.

Johansen, S., 1988. Statistical analysis of cointegrating vectors. Journal of Economic Dynamics and Control 12, 231-254.

Kao, C., Chiang, M.H., 2000. On the estimation and inference of a cointegrated regression in panel. In: Baltagi, B. Fomby, T. B. Hill, C.R. (Eds.), Nonstationary Panels, Panel Cointegration, and Dynamics Panels. In: Advanced in Econometrics, vol. 15. Emerald, pp. 179-222.

Moon, H.R., Perron, B., 2004. Testing for a unit root in panels with dynamic factors. Journal of Econometrics 122, 81-126.

Obstfeld, M., 1986. Capital mobility in the world economy: theory and measurement. Carnegie-Rochester Conference Series on Public Policy 24, 55-103.

Pedroni, P., 2004. Panel cointegration: asymptotic and finite sample properties of pooled time series tests with an application to the PPP hypothesis. Econometric Theory 20, 597-625.

Pesaran, M.H., 2004. General diagnostic tests for cross section dependence in panels. Working Paper 0435, Cambridge.

Taylor, A.M., 1994. Domestic saving and international capital flows reconsidered. NBER Working Paper No. 4892.

Urbain, J.P., Westerlund, J., 2011. Least squares asymptotics in spurious and cointegrated panel regressions with common and idiosyncratic stochastic trends. Oxford Bulletin of Economics and Statistics 73, 119-139.

Westerlund, J., 2006. Testing for panel cointegration with multiple structural breaks. Oxford Bulletin of Economics and Statistics 68, 101-132. 